\title{
LEADERSHIP VERSUS MANAGEMENT
}

Marian-Aurelian Bârgău*

\section{Abstract}

It is important to distinguish the difference between leadership and management, both of which are considered necessary. Leadership and management are often used interchangeably, but they are two distinctive and complementary processes.

Organizations need strong leadership and strong management for optimal effectiveness. In today's dynamic workplace, we need leaders to challenge the status quo and to inspire and persuade organization members. We also need managers to assist in developing and maintaining a smoothly functioning workplace.

Key-words: leadership, management, workplace

JEL Classification : M10, M20

\section{INTRODUCTION}

The present debate about 'management' and 'leadership' is not new. There is a long history of research into what management is, what managers do, and what managers need to have in order to do their jobs well. 'Leadership' has been of interest at different times and in different ways.

The subject of the differences between leadership and management has been discussed at length in the literature. John Kotter (1990) developed a structure for determining the difference between leadership and management behaviour and tasks. Kotter's view was perhaps more extreme than Drucker's, but also supported it to a large degree. Kotter argued that leaders and managers have tasks that are almost opposite in nature. He felt that management works towards order and stability. Management does this because order will lead to consistency, and consistency to smooth and efficientrunning operations - a goal of management. Conversely, Kotter purported that leadership strove to deliver constructive change and movement in organisations. He argued that successful leaders would seek "continual adaptive change" with a goal of continuously

\footnotetext{
*Marian Aurelian Bârgău, Valahia University of Targoviste, marianbargau@yahoo.com
} 
improving organisations for success. Kotter felt that leaders should aspire to continually 3 improve organisations so that they would have a greater chance of survival in a continually adapting business environment and those that stay static will not succeed. Kotter was a strong supporter of both leaders and managers in organisations however, arguing that both were necessary to an organisation that runs effectively. A sense that can be gained from some an academic study by Kotter is that managers make the vision of leaders work. For example, leaders provide a sense of direction, reviewing the big picture, and then creating a vision. Managers take this vision and direction, commit to it and then establish timelines and agendas and secure resources to deliver on this vision. Managers make it happen, according to Kotter.

Management and leadership are terms that are frequently used interchangeably, however, they are not the same thing - they have quite distinct meanings. The two do have similarities but they also have important differences. This research report aims to understand the difference between leadership and management and why these differences are important.

\section{THE DIMENSIONS OF MANAGEMENT}

For most, the definition of management is seen quite differently. This doesn't mean that an individual can't hold both management and leadership responsibilities simultaneously, but management is considered a term separate from leadership. The definition of management is to exercise executive, administrative, and supervisory direction of a group or organization.

Katz defined the management as exercising direction of a group or organization through executive, administrative, and supervisory positions (Katz, 1955). Katz thought that management responsibilities are usually taskedoriented, and it involves developing staff, mentoring persons with high potential, and resolving conflicts while maintaining ethics and discipline (Katz, 1955). Kappa states that the aim from a good management is to provide services to the community in an efficient and sustainable manner (Kappa, 1991). Moreover, Kotter defined the management as a job which takes care of planning, organizing, budgeting, coordinating and monitoring activities for group or organization (Kotter, 2001). Northouse defined the management as a process by which definite set objectives are achieved through the efficient use of resources (Northouse, 2007). Thus, Management in general is a process that is used to achieve organizational goals. Managers focus on formal directing and controlling of their assistants, resources, structures, and systems (Kotter, 2001). Managers aim to reach short term goals, avoid any risks, and establish standardization to improve efficiency (Kotterman, 2006). 
The employees follow a manager's direction in exchange for being paid a salary, known as a transactional style (Kotter, 2001). Research shows thatbeing an effective manager depends upon three special skill sets: technical, human and conceptual. The technical skill refers to the proficiency in a specific type of work. This may include competencies within a specialized field, or the ability to use appropriate tools and techniques. Human skill refers tothe ability to work with people, which allow a manager to assist group members to complete a task. Conceptual skill refers tothe ability to work with ideas (Katz, 1955). In addition, an effective manager needs to have specific qualities like: good communication; organizational; negotiation; and delegation skills (Kappa, 1991).

Because management responsibilities are generally much more task-oriented than some leadership responsibilities, one important way to operationalize effective management is to discuss necessary skills. Skills are different from traits or characteristics in that they are the ability to use one's knowledge and competences to accomplish a set of objectives.

Kristina G. Ricketts afirm that the effective administration depends upon three personal skill sets: technical, human and conceptual. The following is a discussion of each:

- Technical skill: knowledge about and proficiency in a specific type of work or activity. This may include competencies within a specialized field, analytical ability, or the ability to use appropriate tools and techniques.

- Human skill: knowledge about and ability to work with people, often considered "people" skills. These skills allow a manager to assist group members when working cooperatively as a group to achieve a task or assignment.

- Conceptual skill: the ability to work with ideas and concepts. This skill set doesn't involve working with people or things, but focuses on ideas.

Each of these types of skills is important for effective management, and are necessary within different levels of management within a group or organization.

\section{THE DIMENSIONS OF LEADERSHIP}

The word "leadership“ has been used in various aspects of human endeavour such as politics, businesses, academics, social works, etc. Previous views about leadership show it as personal ability. The individual leader traits depends not only on personal abilities and his characteristics, but in special on the characteristics of the situation and environment in which he finds himself. People could become members of an organization in other to achieve certain personal objectives, the extent to which they are active members depends on how they are convinced that their membership will enable them to achieve their predetermined objectives. The leader will support an organization if he 
believes that through it his personal objectives and goals could be met otherwise the person's interest will decline. The type leader or style of leading in an organization is one of the factors that play significant role in enhancing or retarding the interest and commitment of the individuals in the organization.

The term 'leadership' causes considerable confusion. Some people assume leaders are those near the top of organisations and therefore define leadership in such terms, often emphasising strategy and vision. Others use the term 'leadership' to describe the more transformational aspects of management at any level, especially the motivation of employees and the management of change. So in English, the idea of 'leadership' embodies both the heroic leader at the top (Wellington or Nelson) and the brave foot soldier - a pretty confusing mix. Management on the other hand, appears a more mundane and formal affair, the dictionary definition including words like 'direct', 'control' and 'resources.'

Different authors define leadership in different ways, so it can be said that there are almost as many definitions of leadership as there are authors who have attempted to define the concept (Stogdill, 1974, p. 259). From the period when Stogdill noticed this till today, number of those definitions has increased. And from all those definitions, it follows that leadership has been defined in terms of traits, behavior, influence, interaction patterns, role relationship, and occupation of an administrative position (Yukl, 2002, p. 2).

From all these definitions, Yukl concludes that leadership is the process of influencing others to understand and agree about what needs to be done and how it can be done effectively, and the process of facilitating individual and collective efforts to accomplish the shared objectives (Yukl, 2002, p. 7).

Different definitions of leadership style derive from different definitions of leadership. Stogdill (1974) thus finds that leadership style means a method and capability aimed at achieving organizational targets and further affects all organizational activities. Fiedler (1967) states that a leadership style is a type of relationship by which someone uses his rights and methods to influence many employees to work together in pursuit of a common goal.

\section{THE DIFFERENCES BETWEEN MANAGERS AND LEADER}

The literature varies on the core skills of leadership and management. Some researchers have taken a more extreme view, stating that management and leadership perform activities that are almost opposite in nature. For example, in 1990, John Kotter presented a framework for understanding key differences between leadership behaviour and management tasks. It was strongly argued by Kotter that management tries to establish security and order, whereas leadership has the goal of promoting change and fluidity within organizations. 
Kotter proposed that the main function of managers is to drive consistency, which in turn should lead to an efficient-running organization. However, leaders were determined by Kotter to do the converse to this, by seeking "continual adaptive change". Kotter did not mean that leaders were looking for change for change's sake, rather, in such unpredictable times continual change is required for an organization to even survive at all.

The research of Henry Mintzberg found that managers have different roles, the general categories of which include interpersonal, informational, and decisional. Each may be segmented. For example, the interpersonal role includes figurehead and influencer, informational includes monitor and spokesperson, and the decisional role includes entrepreneur and negotiator. Successful managers integrate these various roles and are likely to engage in them without making a clear distinction. Another way to understand managers' work is to identify their competencies, some of which are found in the categorizations discussed earlier. Conceptual, technical managerial/ clinical, interpersonal/collaborative, political, commercial, and governance competencies are used in different proportions by managers at various levels of the organization.

Managers are the people to whom this management task is assigned, and it is generally thought that they achieve the desired goals through the key functions of planning and budgeting, organizing and staffing, problem solving and controlling. Leaders on the other hand set a direction, align people, motivate and inspire (Kotter, 2001).

Paul Birch noticed that in large managers devote more attention to the tasks they have to accomplish while leaders are more concerned about people. That does not imply that leaders do not pay attention to the tasks to be performed, just as tasks and good support is done by other team members. The leader sees people as people, while manager he considered a "resource". Thus, he remarks that management act, namely the phenomenon of the leader, not only manifests itself as a business phenomenon, but also in various fields unrelated businesses.

Other researchers consider that a leader has soul, the passion and the creativity while a manager has the mind, the rational and the persistence. A leader is flexible, innovative, inspiring, courageous and independent and at the same time a manager is consulting, analytical, deliberate, and authoritative and stabilizing (Capowski, 1994).

The most important differences between leaders and managers concern the workplace and are concluded in table I: 
Table I: Comparison of Management and Leadership Process Differences in the workplace (Kotterman,2006).

\begin{tabular}{|c|c|c|}
\hline Process & Management & Leadership \\
\hline Vision Establishment & $\begin{array}{l}\text { Plans and budgets } \\
\text { Develops process steps and } \\
\text { sets timelines } \\
\text { Displays impersonal attitude } \\
\text { about the vision and goals }\end{array}$ & $\begin{array}{l}\text { Sets direction and develop the } \\
\text { vision } \\
\text { Develops strategic plans and } \\
\text { achieve the vision } \\
\text { Displays very passionate attitude } \\
\text { about the vision and goals }\end{array}$ \\
\hline $\begin{array}{l}\text { Human Development } \\
\text { and Networking }\end{array}$ & $\begin{array}{l}\text { Organizes and staffs } \\
\text { Maintains structure } \\
\text { Delegate responsibility } \\
\text { Delegates authority } \\
\text { Implements the vision } \\
\text { Establishes policy and } \\
\text { procedures to implement } \\
\text { vision } \\
\text { Displays low emotion } \\
\text { Limits employee choices }\end{array}$ & $\begin{array}{l}\text { Align organization } \\
\text { Communicates the vision, } \\
\text { mission and direction } \\
\text { Influences creation of coalitions, } \\
\text { teams and partnerships that } \\
\text { understand and accept the vision } \\
\text { Displays driven, high emotion } \\
\text { Increases choices }\end{array}$ \\
\hline Vision Execution & $\begin{array}{l}\text { Controls processes } \\
\text { Identifies problems } \\
\text { Solves problems } \\
\text { Monitor results } \\
\text { Takes low risk approach to } \\
\text { problem solving }\end{array}$ & $\begin{array}{l}\text { Motivates and inspires } \\
\text { Energizes employees to } \\
\text { overcome barriers to } \\
\text { change } \\
\text { Satisfies basic human needs } \\
\text { Takes high risk approach to } \\
\text { problem solving }\end{array}$ \\
\hline Vision Outcome & $\begin{array}{l}\text { Managers vision order and } \\
\text { predictability } \\
\text { Provides expected results } \\
\text { consistently to leadership and } \\
\text { other stakeholders }\end{array}$ & $\begin{array}{l}\text { Promotes useful and dramatic } \\
\text { changes, such as new products or } \\
\text { approaches to improving labor } \\
\text { relations }\end{array}$ \\
\hline
\end{tabular}

\section{CONCLUSION}

Finally, we consider the differences that exist between a manager or a leader and keep perspective. It should be noted that there are many real situations in which the manager does not perform as leader of the group, but one member is the one who directs the team's actions in a particular direction. This aspect is often of conflict due to differences of opinion between the opinion leader and manager and the fact that the latter can consider them as authority is questioned.

Ricketts (2009) also delineates a clear difference between leadership and management, but proposes that an individual can successfully practice both simultaneously if he possesses the right knowledge. However, while Kotter 
considers leadership and management to be complementary because they are equally necessary to achieve organizational aims, Ricketts (2009) focuses on the overlap of the traits that form each one. Because leadership is a group process that utilizes influence to attain goals, and management is an administrative means of supervising and directing, the two are likely to coexist (Ricketts, 2009). Concordantly, leaders often find themselves managing and managers are often compelled to lead, but success at one activity does not guarantee success at the other (Lunenburg, 2011; Ricketts, 2009).

I have found that leadership is the essential tool for commitment from employees. Without a leader, employees lose hope and their commitment to the company is drastically reduced. It's not that they don't want to do better it's that they have no one to inspire them or encourage them to do so. Companies today hug the philosophy of management. They have forgotten what leadership is. Without leadership, all else is lost. Wars are not won on management alone. A leader is essential to inspire an organization to go beyond what they thought possible and to believe it is possible.

\section{ACKNOWLEDGEMENT}

This work was supported by the project "Excellence academic routes in doctoral and postdoctoral research - READ" co-funded from the European Social Fund through the Development of Human Resources Operational Programme 2007-2013, contract no. POSDRU/159/1.5/S/137926.

\section{REFERENCES}

Yukl, G. (2002). Leadership in Organizations. Fifth Edition, Upper Saddle River, New Jersey: Prentice-Hall International, Inc.

Stogdill, R. M. (1974). Handbook of leadership. New York: The Free Press.

Kotter, J. P. (1987), The Leadership Factor, The Free Press, New York, NY.

Kotter, J. P. (1990a). What leaders really do. Harvard Business Review, 68, 103-111.

Kotter, J. P. (1990b). A force for change: How leadership differs from management. New York, NY: Free Press.

Kotter, J. P., (2001), "What leaders really do?", Harvard Business Review, Vol. 79 Issue 11, p.85-96 
Katz, R. L. (1955). Skills of an effective administrator. Harvard Business Review, 33(1), 33-42

Kotterman, J., (2006), “Leadership vs Management: What's the difference?”, Journal for Quality \& Participation, Vol. 29 Issue 2, p.13-17

Capowski, G., (1994), "Anatomy of a leader: where are the leader of tomorrow?”, Management Review, Vol. 83 Issue 3, p.10-18

Collins, J., (2001), "Level 5 Leadership, The Triumph of humility and fierce resolve”, Harvard Business Review, Vol. 79 Issue 1, p.66-76

Ricketts, K. G., 2009. Leadership vs. Management. [pdf] Lexington, KY: University of Kentucky College of Agriculture. Available at: http://www2.ca.uky.edu/agc/pubs/elk1/elk1103/elk1103.pdf

Lunenburg, F. C., 2011. Leadership versus Management: A Key Distinction-At Least in Theory. International Journal of Management, Business, and Administration, 14 (1), p. 1-4 